\title{
JPMS
}

Jurnal Pengabmas Masyarakat Sehat

ARTIKEL HASIL PENGABDIAN KEPADA MASYARAKAT

URL artikel: http://ejournal.poltekkes-denpasar.ac.id/index.php/JPMS/article/view/jpms1407

\section{Penyuluhan Tentang Suntik Tetanus Toksoid Kepada Ibu Hamil Primigravida Di Pesisir Loun}

\author{
Netty Taribuka ${ }^{1 k}$; Mirna Heluth ${ }^{1}$ \\ ${ }^{1}$ Sekolah Tinggi Ilmu Kesehatan Maluku Husada, DIII Kebidanan \\ Email penulis korespondensi $\left({ }^{\mathrm{K}}\right)$ : Taribuka@gmail.com
}

\begin{abstract}
In 2008 there were cases of Tetanus Neonatorum with 91 cases of death or a Case Fatality Rate (CFR) of 55\%. Most of the cases of Tetanus Neonatorum were babies whose deliveries were assisted by traditional birth attendants. Tetanus neonatorum is a tetanus disease that occurs in neonates (infants less than 1 month old) caused by Clostridium tetani, which is a germ that releases toxins that attack central nervous system. Risk factors that cause neonatal tetanus are delivery that does not meet cleanliness, namely umbilical cord care does not meet health requirements and administration of Tetanus Toxoid immunization to pregnant women is not carried out or is incomplete or not in accordance with program provisions. TT immunization is one solution to prevent tetanus neonatorum (TN). WUS who are the targets of TT immunization are women aged 15-49 years consisting of pregnant women (pregnant women) and non-pregnant women. TT immunization on WUS is given as many as 5 doses at certain intervals, starting before and or during pregnancy which is useful for lifelong immunity
\end{abstract}

Keywords: tetanus, pregnancy, primigravida.

\section{Pendahuluan}

Kehamilan pertama bagi seorang ibu (primigravida) merupakan salah satu periode krisis dalam kehidupannya. Kecemasan tersebut dapat muncul karena masa panjang saat menanti kelahiran, dan bayangan tentang hal-hal yang menakutkan saat proses persalinan walaupun belum tentu terjadi. Situasi ini menimbulkan perubahan drastis, bukan hanya fisik tetapi juga psikologis. ${ }^{(1)}$

Kecemasan yang dialami para ibu primigravida menjelang persalinan pertamanya, mulai dari kecemasan akan bayinya jika lahir prematur, cemas terhadap perkembangan janin dalam rahim, cemas terhadap kematian bayinya, cemas terhadap bayinya jika lahir cacat, cemas akan proses persalinan, cemas terhadap kemungkinan komplikasi saat persalinan, cemas terhadap nyeri yang timbul saat persalinan. $^{(2)}$

Gangguan psikologis kecemasan selama kehamilan berhubungan dengan terjadinya indeks resistensi pada arteri uterin. Hal ini disebabkan oleh terjadinya peningkatan konsentrasi noradrenalin dalam plasma darah, sehingga aliran darah ke uterus terganggu. Uterus sangat sensitif terhadap noradrenalin dan dapat menimbulkan efek vasokontriksi. Mekanisme ini yang mengakibatkan 
terhambatnya proses partumbuhan dan perkembangan janin intra uterin karena kurangnya oksigen dan nutrisi sehingga terjadi kejadian berat badan lahir rendah (BBLR). Selain itu, kondisi stres dan cemas dapat merangsang peningkatan hormon kortikotropin yang diketahui berinteraksi dengan hormon oksitoksin dan prostaglandin. Hormon oksitoksin memediasi kontraksi uterus sehingga terjadi kelahiran sebelum waktunya. ${ }^{(3)}$

Pada tahun 2008 terjadi kasus Tetanus Neonatorum dengan kematian sejumlah 91 kasus atau Case Fatality Rate (CFR) 55\%. Dari kasus Tetanus Neonatorum tersebut sebagian besar adalah bayi yang persalinannya ditolong oleh dukun bersalin. Penyakit tetanus neonatorum adalah penyakit tetanus yang terjadi pada neonatus (bayi berusia kurang dari 1 bulan) yang disebabkan oleh Clostridium tetani, yaitu kuman yang mengeluarkan toksin (racun) yang menyerang system syaraf pusat. Faktor risiko yang menyebabkan tetanus neonatorum adalah persalinan yang tidak memenuhi 3 bersih yaitu perawatan tali pusat tidak memenuhi persyaratan kesehatan dan pemberian imunisasi Tetanus Toxoid pada ibu hamil tidak dilakukan atau tidak lengkap atau tidak sesuai dengan ketentuan program. ${ }^{(4)}$

Imunisasi TT merupakan salah satu solusi untuk mencegah terjadinya tetanus neonatorum (TN). WUS yang menjadi sasaran imunisasi TT adalah wanita berusia antara 15-49 tahun yang terdiri dari WUS hamil (ibu hamil) dan tidak hamil. Imunisasi TT pada WUS diberikan sebanyak 5 dosis dengan interval tertentu, dimulai sebelum dan atau saat hamil yang berguna bagi kekebalan seumur hidup. ${ }^{(5)}$ Tujuan imunisasi Tetanus Toksoid ini untuk melindungi ibu dan bayi dari penyakit tetanus karena antibodi dihasilkan dan diturunkan pada bayi melalui plasenta dan mengurangi resiko tetanus pada neonatal. ${ }^{(6)}$ Meskipun imunisasi tetanus pada ibu hamil dinilai sangat penting sebagai bentuk pencegahan Tetanus pasca persalinan, maupun pada bayi yang dilahirkan sang ibu, pemanfaatan imunisasi TT pada ibu hamil dinilai masih kurang optimal. ${ }^{(7)}$

Hasil yang diperoleh dari data profil kesehatan Indonesia pada tahun 2013, dilaporkan bahwa Indonesia memiliki 78 kasus kematian Tetanus Neonatorum yang diakibatkan oleh infeksi tetanus, jumlah tersebut meningkat dibandingkan dengan data kematian akibat Tetanus Neonatorum di Indonesia pada tahun 2012 yang berjumlah 42 kasus. Setelah dilakukan penelitian lebih mendalam pada kasus kematian yang meningkat, maka diperoleh hasil penyebab kematian Tetanus Neonatorum terjadi pada kelompok bayi yang tidak pernah mendapatkan imunisasi Tetanus Toksoid yaitu 51 kasus, 55 kasus melakukan pemeriksaan kehamilan dengan bidan atau perawat. Namun, berdasarkan faktor penolong persalinan, 56 kasus ditolong oleh persalinan tradisional, misalnya dukun. Pemotongan tali pusat, sebagian besar kasus dilakukan pemotongan tali pusat dengan gunting yaitu 55 kasus. ${ }^{(8)}$

Target yang ditetapkan oleh pemerintahan Indonesia mengenai program imunisasi Tetanus Toksoid saat kehamilan sebesar $80 \%$, namun pada kenyataannya target yang dicapai belum sesuai dengan target nasional yang telah ditetapkan. Ibu dengan status TT1 sebesar 23,4\%, ibu hamil dengan status TT2 sebesar 21,8\%, ibu dengan status TT3 sebesar 9,4\%, ibu dengan status TT4 sebesar 7,8\%, ibu dengan status TT5 sebesar $8,2 \%$, dan TT2+ sebesar 47,3\%. ${ }^{(9)}$ 
Target nasional dari semua program imunisasi lengkap adalah 80\%. Meskipun program imunisasi TT pada WUS telah dilaksanakan tetapi jangkauan imunisasi TT bagi WUS khususnya TT 5 masih jauh dari harapan. Profil data kesehatan Indonesia tahun 2015 menunjukan cakupan imunisasi TT 5 pada WUS di Indonesia yakni sebanyak 4,45\%. Sedangkan di Daerah Istimewa Yogyakarta cakupan imunisasi TT 5 sebanyak 2\%. Angka ini sangat rendah dibanding dengan provinsi lain, misalnya Jawa Timur cakupan imunisasi TT 5 sebanyak 21,62\%, Bali 4,48\%, Jawa Tengah 4,14\%, Bangka Belitung 3,71\%, Maluku 3,32\% bahkan Papua Barat lebih tinggi yakni 2, 13\%. Rendahnya cakupan imunisasi TT ini menunjukkan bahwa pemanfaatan imunisasi TT pada WUS masih belum optimal. ${ }^{(10)}$

\section{Metode Pengabdian}

Kegiatan pengabdian kepada masyarakat dilaksanakan di Desa Loun, dilaksanakan pada bulan Agustus 2019. Sasaran dari kegiatan pengabdian masyarakat ini adalah para ibu hamil yang berada di lokasi penelitian. Kegiatan pengabdian ini berupa penyuluhan mengenai suntik tetanus toksoid pada ibu hamil primigravida menggunakan media leaflet, laptop, LCD, kuesioner dan speaker. Pada kegiatan pengumpulan data akan dilakukan pre-test dan post-test mengenai pengetahuan sampel. Teknik pengumpulan data yang digunakan adalah teknik sampling aksidental yaitu siapa saja yang secara kebetulan bertemu dengan peneliti dapat digunakan sebagai sampel penelitian sesuai dengan kriteria inklusi dan eksklusinya. Dalam kegiatan pengabdian masyarakat ini pengolahan dan analisis data menggunakan analisis univariat, hasil kuesioner yang didapatkan akan di tabulasi kemudian di analisis secara manual dan dibuatkan pembahasan.

\section{Hasil dan Pembahasan}

\section{A. Hasil}

\section{Hasil Pre-test dan Post-test Pengetahuan Tentang Suntik Tetanus Toksoid Pada Ibu Hamil Primigravida}

Dari hasil data penelitian menunjukan bahwa adanya peningkatan pengetahuan ibu hamil tentang suntik tetanus toksoid sebesar $90 \%$ Pengetahuan ibu hamil mengenai suntik tetanus toksoid yang benar saat pre-test sebesar $16,7 \%$ setelah dilakukan penyuluhan tentang suntik tetanus toksoid pada ibu hamil untuk mencegah tetanus, pengetahuan ibu hamil mendapatkan pemahaman dan pengetahuan sehingga nilai post-test naik yaitu sebesar 90\%. Data selengkapnya dapat dilihat pada tabel 1 .

Tabel 1. Hasil Pre-test dan Post-test Pengetahuan Tentang Suntik Tetanus Toksoid Pada Ibu Hamil Primigravida

\begin{tabular}{ccccccc}
\hline \multirow{2}{*}{ No } & \multicolumn{3}{c}{ Pre-test } & \multicolumn{3}{c}{ Post-test } \\
\cline { 2 - 7 } & Pengetahuan & $\mathrm{f}$ & $\%$ & Pengetahuan & $\mathrm{f}$ & $\%$ \\
\hline 1 & Baik & 5 & 16,7 & Baik & 27 & 90,0 \\
2 & Kurang & 25 & 83,3 & Kurang & 3 & 10,0 \\
\hline & Jumlah & 30 & 100,0 & Jumlah & 15 & 100,0 \\
\hline
\end{tabular}




\section{B. Pembahasan}

Rendahnya pengetahuan ibu karena dipengaruhi ketidaktahuan ibu tentang manfaat suntik tetanus toksoid. Rendahnya pengetahuan ibu tentang tablet suntik tetanus toksoid dapat menyebabkan angka tetanus di Indonesia semakin meningkat. Ibu hamil penting untuk mendapatkan pengetahuan mengenai suntikan tetanus toksoid yang merupakan salah satu cara mencegah tetanus mengingat dampak tetanus dapat menurunkan kualitas SDM di Indonesia.

Dalam kegiatan pengabdian ini masyarakat aktif dalam mengikuti kegiatan penyuluhan dari awal dilaksanakan sampai akhir dilaksanakan. Peserta pengabmas aktif dalam sesi tanya jawab. Kegiatan pengabmas ini selain memberikan penambahan pengetahuan dan wawasan juga memperbaiki pola pikir ibu tentang suntik tetanus toksoid beserta manfaatnya.

Sebelum dilakukan penyuluhan terlebih dulu dilakukan pre-test tentang suntik tetanus toksoid yang kuesionernya disebarkan oleh mahasiswa lalu dilakukan sesi penyuluhan dengan memberikan leaflet terlebih dahulu lalu memulai materi penyuluhan yang dibawakan oleh mahasiswa. Setelah sesi materi tiba sesi tanya jawab dengan menggunakan metode diskusi aktif yang dijawab oleh dosen. Setelah sesi diskusi mahasiswa menyebar kuesioner kembali untuk melakukan evaluasi pengetahuan pada ibu. Kemudian hasil data penelitian dibuatkan tabulasi data dan dilakukan analisis menggunakan hitungan manual lalu hasil hitungan manual dideskripsikan.

Dengan adanya penyuluhan ini terbukalah wawasan ibu tentang suntik tetanus toksoid dan manfaatnya. Diharapkan dengan adanya pengabdian ini dapat mengubah pola pikir ibu dan angka tetanus di Indonesia dapat berkurang.

\section{Simpulan dan Saran}

Adanya peningkatan kenaikan pengetahuan tentang suntik tetanus toksoid baik sebesar $90 \%$. Faktor yang memengaruhi pengetahuan ibu tentang suntik tetanus toksoid ialah ibu tidak mencari tahu informasi mengenai pencegahan tetanus dengan memberi suntikan tetanus toksoid pada ibu. Dengan adanya kegiatan pengabdian masyarakat ini pengetahuan ibu dapat meningkat dan merubah kebiasaan yang salah menjadi kebiasaan yang benar sehingga prevalensi tetanus dapat berkurang.

Disarankan bahwa penyuluhan mengenai suntik tetanus toksoid dapat dilakukan menyeluruh sehingga dapat diharapkan dengan adanya penyuluhan ini wawasan ibu mengenai suntik tetanus toksoid dapat bertambah. Dan dapat menyadarkan ibu untuk tetap menjalankan pola hidup sehat dan tetap menjaga kebersihan agar terhindar dari tetanus.

\section{Daftar Pustaka}

1. Janiwarty B. \& Pieter H.Z. Pendidikan Psikolog Untuk Bidan. Rapha Publishing. Medan.2012

2. Keswamas. Kesehatan Jiwa Pada Ibu Hamil. 2008

3. Usman FR, Kundre RM, Onibala F. Perbedaan Tingkat Kecemasan Ibu Hamil Menghadapi Persalinan Dengan Kepatuhan Antenatal Care (ANC) di Puskesmas Bahu Kota Manado. Universitas Sam Ratulang; 2016. Available from: https://ejournal.unsrat.ac.id/index.php/jkp /article/view/10794/10383. 
4. Saifuddin dkk, Buku Acuan Nasional Pelayanan Kesehatan Maternal Dan Neonatal. Jakarta: Yayasan Bina Pustaka Sarwono Prawirohardjo.2006

5. Lisnawati, Lilis. Generasi Sehat Melalui Imunisasi. Jakarta : Trans Info Media.2011

6. Wijayanti, Ida dkk. Hubungan Pengetahuan dan Sikap Terhadap Imunisasi TT dengan Pemberian Imunisasi TT Pada Ibu Hamil Di Puskesmas Jambu Kabupaten Semarang. KTI. 2013. Available On: http://perpusnwu.web.id

7. Pratiwi, Cindy. Faktor Yang Berhubungan Dengan Kelengkapan Imunisasi Tt Pada Ibu Hamil Di Puskesmas Tabongo Kecamatan Tabongo Kabupaten Gorontalo. Skripsi. Gorontalo: Fakultas Kedokteran , Universitas Negeri Gorontalo. 2013. Available on: http://kim.ung.ac.id

8. Zulkifli, A. Faktor Risiko Kematian Neonatal Dini Di Rumah Sakit Bersalin. Jurnal Kesehatan Masyarakat.2012. Vol 6, No 6: 283- 288.

9. Kementerian Kesehatan. Peraturan Menteri Kesehatan Republik Indonesia Nomor 12 Tahun 2017 Tentang Penyelenggaraan Imunisasi. Jakarta: Kementerian Kesehatan Republik Indonesia. 2017

10. Ditjel PP \& PL. Peraturan Menteri Kesehatan Nomor 42 Tahun 2013 Tentang Penyelenggaraan Imunisasi. 2013 